\title{
Strategy of Department of Industry and Cooperation of Pidie Jaya District in Developing Small and Medium Micro Enterprises
}

\author{
Zulfikar $^{1}$, Mimin Suriadi ${ }^{2}$ \\ ${ }^{1}$ Universitas Jabal Ghafur, Indonesia \\ ${ }^{2}$ College of Management Sciences, Meulaboh Indonesia \\ Zulfikarmila1990@gmail.com
}

\begin{abstract}
The importance of UMKM for various parties makes it often the object of study and research which mostly discusses its development. This study deals with strategy of department of industry and cooperation of Pidie Jaya District in developing small and medium micro enterprises. This study use a descriptive qualitative. The results are there are two strategy of the Pidie Jaya trade industry and cooperatives service in developing small and medium enterprises:1) capital provision strategy; 2) Training / Empowerment Strategy. There are four efforts that improved micro, small and medium enterprises in Pidie Jaya Regency: 1) strength-opportunity strategy; 2) strength-threat strategy; 3) weakness-opportunity strategy; 4) weakness-threat strategy. It can be concluded that: (1). Capital strategy: assistance provided by the government is very supportive of community UKM, but in terms of capital / loans, UKM expect the government to allocate more budget considering that capital or raw materials and machines are so expensive. (1)The training strategy, the training strategy provided by the agency is very useful for the business community in Pidie Jaya district.
\end{abstract}

\section{Keywords}

strategy, industry, small and medium miceo enterprises

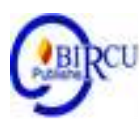

\section{Introduction}

In the current era of globalization, every region must have problems, including economic problems, micro, small and medium enterprises or commonly abbreviated as MSMEs have an important position in developing their economy, not only in the absorption of labor and the welfare of the community, but can also stabilize social inequality problem. The development micro, small, medium enterprises (UMKM) needs to be optimized because the existence of small, medium enterprises (UMKM) makes a major contribution to regional economic development,

The importance of UMKM for various parties makes it often the object of study and research which mostly discusses its development. You can imagine if the small, medium enterprises(UMKM) sector continues to experience growth and quality improvement (management, finance, product output, and marketing), it will become the driving force for the national economy which has been tested immune to the global economic crisis. Although sometimes they are still underestimated, the existence and contribution of MSMEs to the national economy is still vital and strategic.

UMKM actors in Pidie Jaya hardly touch and care at all from the Pidie Jaya Regency Government, to develop small and medium enterprises that they have been working on for years, like the adage "life is reluctant to die and doesn't want." 
From the description above, the researcher is interesting to conduct a research entitled "Strategy of the Pidie Jaya Regency Trade and Cooperative Industry Service in the Development of Micro, Small and Medium Enterprises".

\section{Review of Literature}

\subsection{Strategy}

Strategy comes from the Greek word strategos, which means General. Therefore the word strategy literally means "Art and General". This term refers to what is the top management concern of an organization. In particular, strategy is the placement of the company's mission, setting organizational goals by binding external and internal forces, formulating specific policies and strategies to achieve goals and ensure their proper implementation, so that the main goals and objectives of the organization will be achieved.

Rangkuti (2003: 183) argues that strategy is a comprehensive master plan, which explains how the company will achieve all the goals that have been set based on the mission that has been previously set.

Meanwhile, according to David (2006: 18) Strategy is a shared means with long-term goals to be achieved. Business strategies include geographic expansion, diversification, acquisition, product development, market penetration, tightening, divestment, liquidation, and joint ventures or joint ventures.

Strategy is planning to achieve goals in developing the concept of procedures to be carried out. A strategy contains tips, ways, and tactics prepared systematically and comprehensively to achieve the goals and consist of the ways to create effective relations between organizational resources with the environment both inside and outside the organization (Suprayitno, 2019).

\subsection{Micro Small and Medium Enterprises}

The current lack of solid Indonesian economic fundamentals has prompted the government to continue to empower Micro, Small and Medium Enterprises (UMKM).

This sector is able to absorb quite a large number of workers and provides opportunities for UMKM to develop and compete with companies that tend to use large capital (capital intensive). The existence of UMKM cannot be doubted because they have proven to be able to survive and become the driving force of the economy, especially after the economic crisis.

The economy in Indonesia currently uses a populist economic system where the economic system is based on the strength of the people's economy, where the community holds an active role in economic activities, while the government creates a healthy climate for the growth and development of the business world (Rosmika, 2019).

On the other hand, MSMEs also face many problems, namely limited working capital, low human resources, and lack of mastery of science and technology (Sudaryanto and Hanim, 2002). Another obstacle faced by UMKM is the connection with unclear business prospects as well as unclear planning, vision and mission.

Indeed, the empowerment of UMKM is a synergistic movement between various parties. However, the government still plays the biggest role in these empowerment efforts. Government involvement in empowering UMKM has been clearly regulated in Law no. 20 of 2008 concerning UMKM. 


\section{Research Methods}

In this study the authors use a descriptive qualitative approach limited to efforts to reveal a problem or situation or event as it is so that it is to reveal facts and provide an objective picture of the actual situation of the object under study, then Sugiyono (2010: 11) argues that qualitative research aims to reveal qualitative information so that it emphasizes process and meaning problems by describing a problem

\section{Resluts and Discusssion}

\subsection{Results}

a. The Strategy of the Pidie Jaya Trade Industry and Cooperatives Service in Developing Small and Medium Enterprises

The role of the Office of Industry, Trade and Cooperatives is very important for the development and development of the economic sector, because of the role and support of the government in formulating policies for initial steps to be taken to carry out development in the economic sector. This can all work because there is government intervention that regulates, supervises, and follows up on various problems that occur and can accelerate the movement in the economic sector with policies formulated by the government. However, it is not only the intervention that is carried out by the government, but also the process of society in running its economy.

\section{Capital Provision Strategy}

The Department of Industry, Trade and Cooperatives of Pidie Jaya Regency in an effort to support rural economic activities, especially by providing assistance such as production tools, namely sewing machines, threads and needles. The provision of assistance is held once a year, but must go through several conditions, namely there must be a member of the UKM (group) and then make a proposal that is submitted to the Office of Industry, Trade and Cooperatives.

According to the results of an interview with the secretary of the Head of Industry, he said that the sewing machine assistance provided was by submitting a proposal by the patchwork business group to the Department and after that it was processed by the Service and submitted to the executive, it took 1-2 months to disburse the assistance.

According to the results of an interview with one of the members of the business group, all received assistance, many of us (workers) who are less well off with the help of sewing machines can study hard for the welfare of our group members

According to the author, the provision of assistance and loan capital provided by the Department of Industry, Trade and Cooperatives to SMEs is very minimal. Due to the fact that the production material needs are very much and the demand is very large, the Rp. $20,000,000$ capital is not enough. So that many business owners are not interested in borrowing from the Office of Industry, Trade and Cooperatives, most of them borrow business capital from private banks.

\section{Training / Empowerment Strategy}

The district regional government coordinates with sub-districts to participate in coaching activities. The Office of Industry, Trade and Cooperatives of Pidie Jaya Regency 
conducts training and guidance or empowerment activities for business owners and workers for 1 to 2 times a year.

From the results of the interview from the Head of Industry, the Dinas provides entrepreneurship training which is carried out 3 times a year by inviting speakers from outside the city such as entrepreneurs from Banda Aceh City, then the training is carried out in a place which is attended by 20 group leaders and group members. The content of the socialization that was held was to provide understanding or knowledge such as how to cultivate SMEs, management both in terms of marketing and in promoting them. From the various efforts that have been made, the government hopes that SMEs in Pidie Jaya can penetrate the international market and can be proud of their region.

From the results of an interview with a sewing business actor, he said that the training held by the Dinas seemed to be catching up with time and many of us had left behind the material provided so that the training that was given just floated up.

From the results of the research it can be concluded that: the government has played an active role in providing training to the community so far, but there are obstacles for the community who take the training, which on average only take part in training because of the honorarium earned and the training providers sometimes give too much time so that the community those who did attend the training felt that the material provided by the speakers was left behind.

\section{b. What Efforts Are Taken to Improve Micro, Small and Medium Enterprises in Pidie Jaya Regency}

From the results of the description of the existing problems, alternative strategies that can be carried out by the Pidie Jaya Regency Trade Industry Service are as follows:

\section{SO Strategy (Strength-Opportunity)}

This strategy is a combination of internal factors (Strength) and external factors (Opportunity), this strategy is made by utilizing all strengths to seize and take advantage of the greatest opportunity by the Pidie Jaya Regency Trade Industry Service. SO strategy taken is by optimizing activity funds that come from the APBD. All funds used to carry out a work program by the Office are obtained from the APBD (Regional Revenue and Expenditure Budget) funds. This fund must be optimized in the context of UMKM development activities. By relying on all the strength they have, it is hoped that by optimizing the APBD funds, the Pidie Jaya Regency Trade Industry Service can increase the development of UMKM in Langkat Regency.

\section{ST (Strength-Threat) Strategy}

This strategy is a combination of internal factors (Strength) and external factors (Threat), this strategy uses the strengths of the Cooperatives and UKM Office to overcome all existing threats. The ST strategy adopted by the Pidie Jaya Regency Trade Industry Service is to optimize work programs so that they are of higher quality.

As it is known, every work program implemented by the Pidie Jaya Regency Trade Industry Service is derived from the central government policy, in this case the Ministry of Cooperatives and UMKM. Even so, not all strategies from central policies can be applied in Pidie Jaya District. The Pidie Jaya Regency Trade Industry Service has the right to implement a strategy in accordance with the conditions in Pidie Jaya Regency. Optimizing work programs so that they are of higher quality must be done so that the goal of developing 
UMKM can be more easily achieved, for example in the work program of providing grant assistance. This grant assistance must be right on target and if given it will indeed support the development of the business. Likewise on other work programs.

\section{WO (Weakness-Opportunity) Strategy}

This strategy is a combination of internal factors (Weakness) and external factors (Opportunity). This strategy is applied based on the use of existing opportunities by reducing the weaknesses of the company. The WO strategy pursued by the Pidie Jaya Regency Trade Industry Service is by expanding the reach of empowering UMKM so that their guidance is evenly distributed. In reaching all remote areas to empower UMKM. By expanding the reach of empowerment, the development of UMKM will be evenly distributed, so that problems such as low human resource education for UMKM players will be resolved by conducting coaching so that business actors will no longer have difficulty developing their business.

\section{WT (Weakness-Threat) Strategy}

This strategy is a combination of internal factors (Weakness) and external factors (Threat). This strategy is based on defensive activities and tries to avoid the possibility of external threats to reduce company weakness. The WT strategy pursued by the Pidie Jaya Regency Trade Industry Service is to foster the entrepreneurial spirit of UMKM actors.

An entrepreneurial spirit must be possessed by every UMKM actor because if a business actor has a high entrepreneurial spirit, he will be smart in seeing business opportunities and understand how to respond to and anticipate failure. UMKM players in Pidie Jaya Regency generally have a low entrepreneurial spirit and a low level of education. Therefore it is necessary to make efforts to foster the entrepreneurial spirit of MSME actors, of course by implementing work programs related to strategies such as conducting training.

\subsection{Discussion}

\section{a. The Strategy of the Pidie Jaya Trade Industry and Cooperatives Service in Developing Small and Medium Enterprises.}

From the results of the research that has been done, the researcher will discuss the following results:

The Department of Industry, Trade and Cooperatives of Pidie Jaya Regency in an effort to support rural economic activities, especially by providing assistance such as production tools, namely sewing machines, threads and needles. The provision of assistance is held once a year, but must go through several conditions, namely there must be a member of the UKM (group) and then make a proposal that is submitted to the Office of Industry, Trade and Cooperatives. The sewing machine assistance provided is by submitting a proposal by the patchwork business group to the Department and after that it is processed by the Office and submitted to the executive, it will take 1-2 months to disburse the aid.

As for the capital proposed by the UKM group, it must go through stages that must be in accordance with the requirements for working capital loans. Submission of conditions so that getting a loan must go through stages such as having a productive business, having a permanent domicile, having to have an official letter of business establishment, and those who still have arrears cannot be given additional business capital and then submitted to the Department. The capital that will be obtained is only Rp. 20,000,000.00 and the interest on the loan is fixed. 
The district regional government coordinates with sub-districts to participate in coaching activities. The Office of Industry, Trade and Cooperatives of Pidie Jaya Regency conducts training and guidance or empowerment activities for business owners and workers for 1 to 2 times a year.

The Pidie Jaya Regency Office of Industry, Trade and Cooperatives, appointed one person in the business group to serve as a business group facilitator. The business group facilitator is tasked with finding group members to be recommended to take part in programs such as entrepreneurship training held by the Office of Industry, Trade and Cooperatives which aims to innovate more in UKM production activities so that they can be more optimal and can compete with other regions. The agency provides entrepreneurship training which is carried out 3 times a year by inviting speakers from outside the city such as entrepreneurs from Banda Aceh City, then the training is carried out in a place which is attended by 20 group leaders and group members. The content of the socialization that was held was to provide understanding or knowledge such as how to cultivate UKM, management both in terms of marketing and in promoting them. From the various efforts that have been made, the government hopes that SMEs in Pidie Jaya can penetrate the international market and can be proud of their region.

The Office of Industry, Trade and Cooperatives of Pidie Jaya Regency is perfect in providing more knowledge, so it will be able to help business owners and workers in managing their business. However, in reality most of them did not attend the socialization due to lack of information

\section{Conclusion}

Based on the formulation of the problem and the results of the research, it can be concluded that: (1).Capital strategy: assistance provided by the government is very supportive of community UKM, but in terms of capital / loans, UKM expect the government to allocate more budget considering that capital or raw materials and machines are so expensive. (1)The training strategy, the training strategy provided by the agency is very useful for the business community in Pidie Jaya district.

\section{References}

Abidin, Ali Zaenal. (2017). Strategi Pengembangan Usaha Mikro, Kecil dan Menengah Dinas Koperasi dan UKM Kota Tanggerang Selatan. Juli 2017

David dan Fred R. (2006). Manajemen Strategi: konsep-konsep. Jakarta: INDEKS Kelompok Gramedia.

Kuncoro, Mudrajad. (2000). Ekonomi Pembangunan: Teori, Masalah dan Kebijakan. Yogyakarta: UPP AMP YKPN

Pratiwi, Sundari. (2016). Strategi Pemberdayaan UMKM Sektor Peternakan Ayam Organik (Studi Pada Koperasi Hidayah Sumatera Utara). Skripsi, Fakultas Ekonomi dan Bisnis Islam UINSU.

Punaji Setyosari. (2013). Metode Penelitian Pendidikan dan Pengembangan. Jakarta: Kencana Prenadamedia Group.

Rangkuti, Freddy. (2003). Analisis SWOT Teknik Membedah Kasus Bisnis. Jakarta: Gramedia Pustaka Utama. 
Rosmika, T.E., Mulia, A., and Chairy, P. (2019). The Role of BRI Bank Medan Perjuangan Unit for Customer's Households, Indonesia. Budapest International Research and Critics Institute-Journal (BIRCI-Journal), 2(4): 363-374.

Sudaryanto dan Hanim, Anifatul. (2002). Evaluasi kesiapan UKM Menyongsong Pasar Bebas Asean (AFTA): Analisis Perspektif dan Tinjauan Teoritis. Jurnal Ekonomi Akuntansi dan Manajemen,

Sugiyono. (2010). Metode Penelitian Pendidikan Pendekatan Kuantitatif, kualitatif, dan R\&D. Bandung: Alfabeta.

Suprayitno, Triyani, and Pratiwi, P.F.P. (2019). Strategy on the National Unity and Politics Agency (KESBANGPOL) in Maintaining Ethnicity and Religious Relations Based on Huma Betang Philosophy in Central Kalimantan. Budapest International Research and Critics Institute-Journal (BIRCI-Journal), 2(4): 229-238. 